\title{
The alkali problem in the crystal structure of beta alumina
}

\author{
By J. FeLsche*
}

Massachusetts Institute of Technology, Cambridge, Massachusetts

(Received January 22, 1968)

\section{Auszug}

Die Struktur von Natrium $-\beta-\mathrm{Al}_{2} \mathrm{O}_{3}$ wurde mit dreidimensionalen Daten neu bearbeitet. Hierbei interessierte vor allem die weniger stabile Natrium-Sauerstoff-Schicht, welche die spinellartigen Blöcke der Struktur verbindet. Der Strukturvorschlag von BragG, GotTFried und West (1931) bzw. BeEvers und Ross (1937) erwies sich als grundlegend richtig. In der Verbindungsschicht wurde jedoch ein Mangel an Natrium und Sauerstoff festgestellt. Dieser Befund macht es möglich, die bei $\beta-\mathrm{Al}_{2} \mathrm{O}_{3}$ beobachtete Streuung der Natriumgehalte zu verstehen. In mehreren Verfeinerungszyklen der Parameter nach der Methode der kleinsten Quadrate ergab sich für 181 Interferenzen ein $R$-Faktor von $4,3 \%$.

\section{Abstract}

The crystal structure of sodium beta alumina was reinvestigated by means of three-dimensional data. Of special interest was the less stable sodium-oxygen layer by which the spinel-like blocks of the structure are held together. The original structure determined by BraGG, GOTTFRIED and WEST (1931) and by Bemvers and Ross (1937) turned out to be fundamentally correct. A deficiency of sodium and oxygen was found however in the interlayer. This fact makes it possible now to understand the wide range of sodium concentration reported for this compound. Several cycles of least-squares refinement reduced the disagreement factor $R$ for 181 reflections to a final value of $4.3 \%$.

\section{Introduction}

The name $\beta \mathrm{Al}_{2} \mathrm{O}_{3}$ derives from the assumption that this substance is one of the alotropic forms of aluminum oxide. When BRAGG, GotTFRIED and WEST (1931) started the first crystal-structure determination, the material was known to contain some sodium. Previously STILLwell (1926) had already stated that the presence of sodium oxide was essential for the syntheses of $\beta-\mathrm{Al}_{2} \mathrm{O}_{3}$ crystals, which form thin hexagonal plates parallel to (0001), a plane of perfect cleavage. The crystal-structure investigation turned out to be difficult. The

\footnotetext{
* Present address: Institut für Kristallographie und Petrographie der Eidg.
} Techn. Hochschule, Zürich. 
authors hesitated to assume a structure based on the formula $\mathrm{Na}_{2} \mathrm{Al}_{22} \mathrm{O}_{34}$ because, while consistent with space group $P 6_{3} / m m c$, it was not in agreement with the ehemical analysis for sodium or the density measurement. Beevers and Ross (1937), however, confirmed the structure proposed on the basis of the 'ideal' formula $\mathrm{Na}_{2} \mathrm{Al}_{22} \mathrm{O}_{34}$, as well as its isomorphic form $\mathrm{K}_{2} \mathrm{Al}_{22} \mathrm{O}_{34}$. Their work was based on a different chemical analysis of higher quality as mentioned by the authors. Although excellent agreement of calculated and observed structure factors was obtained, one problem could not be clarified satisfactorily namely the position of the alkali atoms, which may be in either [001] or $\left[\frac{21}{3} \frac{1}{4}\right]$ if the origin of the cell is taken at one of the centres of symmetry. It has been argued lately by SAALFELD (1956) that sodium beta alumina may not have a stoichiometric composition at all. Chemical analysis for sodium content have reported results ranging from 2.7 to 8.6 wt. $\% \mathrm{Na}_{2} \mathrm{O}$. A reinvestigation of the crystal structure and a detailed study of the sodium-oxygen interlayer has been carried out now by means of three-dimensional intensity data.

\section{Unit cell and space group}

Crystals were taken from the center of a corroded fusion-cast betaalumina refractory block which had been used for about two years as superstructure material in a tank for sheet glass. Because of the excellent cleavage parallel to (0001) it was very difficult to obtain single crystals.

Precession photographs showing systematic extinctions were used to determine the diffraction symbol $6 / \mathrm{mmm} C-/--c$. Possible space groups are $C \overline{6} 2 c, C 6 m c$ and $C 6 / m m c$. This agrees with the first spacegroup determination of beta alumina reported by HENDRICKs and Pauling (1927).

Precise values for the length of the $a$ and $c$ axes were obtained from a back-reflection Weissenberg photograph. The data were adjusted by means of a least-squares calculation. The values of the cell dimensions thus obtained together with those given by former authors are listed in Table 1.

Table 1. Unit cell dimensions of sodium beta alumina

\begin{tabular}{l|l|l}
\hline \multicolumn{1}{c|}{} & \multicolumn{1}{|c|}{$c$} & \multicolumn{1}{c}{ Authors } \\
\hline $5.60 \AA$ & $22.414 \AA$ & HENDRICKS and PAULING (1927) \\
5.56 & 22.55 & BRAGG et al. (1931) \\
5.584 & 22.45 & BEEVERS and Ross (1937) \\
$5.596_{2}$ & $22.52_{6}$ & FELSCHE
\end{tabular}




\section{Intensity data}

A small rectangular prism of a sodium beta-alumina crystal $(0.15 \times 0.11 \times 0.085 \mathrm{~mm})$ was selected for intensity measurement. An equi-inclination diffractometer employing a proportional counter was used to collect integrated intensities with nickel-filtered $\mathrm{Cu} K \alpha$ radiation. The $\lambda / 2$ harmonic was removed by pulse-height analysis.

\begin{tabular}{|c|c|c|c|c|c|c|c|c|c|c|c|c|c|c|}
\hline k 1 & $\mathbf{F}_{o}$ & $F_{c}$ & h k I & $F_{a}$ & $F_{c}$ & h $k 1$ & $F_{0}$ & $\mathrm{~F}_{\mathrm{c}}$ & $\mathrm{h} k 1$ & $\mathrm{~F}_{\mathrm{O}}$ & $F_{c}$ & $\mathrm{~h} \times \mathrm{k}$ & $x_{0}$ & $F_{0}$ \\
\hline $\begin{array}{r}04 \\
6 \\
6\end{array}$ & $\begin{array}{r}145.7 \\
39.8\end{array}$ & $\begin{array}{r}147.2 \\
39.9\end{array}$ & $02 \frac{4}{5}$ & $\begin{array}{r}42.5 \\
98.6\end{array}$ & $\begin{array}{l}41.3 \\
96.3\end{array}$ & $\begin{array}{llll}0 & 4 & 11\end{array}$ & $\begin{array}{l}78.4 \\
22.4\end{array}$ & $\begin{array}{r}78.8 \\
21.8\end{array}$ & 1213 & 33.4 & 37.9 & 226 & 22,5 & 19.7 \\
\hline & $\begin{array}{r}58.9 \\
67.0\end{array}$ & $\begin{array}{l}39.9 \\
55.4\end{array}$ & & $\begin{array}{r}98.6 \\
111.0\end{array}$ & $\begin{array}{r}96.3 \\
110.9\end{array}$ & $\begin{array}{l}12 \\
13\end{array}$ & $\begin{array}{l}22.1 \\
110.0\end{array}$ & $\begin{array}{r}21.8 \\
110.3\end{array}$ & $\begin{array}{l}14 \\
15\end{array}$ & $\begin{array}{l}26.1 \\
11.9\end{array}$ & $\begin{array}{l}26.7 \\
10.6\end{array}$ & $\begin{array}{r}8 \\
14 \\
14\end{array}$ & $\begin{array}{l}40.5 \\
80.2\end{array}$ & $\begin{array}{l}\begin{array}{l}2.8 .8 \\
77.2\end{array}\end{array}$ \\
\hline & & & & $\begin{array}{l}94.3 \\
69.3\end{array}$ & $\begin{array}{l}94.6 \\
68.3\end{array}$ & $\begin{array}{l}14 \\
17\end{array}$ & $\begin{array}{l}110.1 \\
22.3\end{array}$ & $\begin{array}{r}107.5 \\
22.6\end{array}$ & $\begin{array}{l}16 \\
17 \\
17\end{array}$ & $\begin{array}{l}13.4 \\
24.3\end{array}$ & $\begin{array}{l}15.4 \\
27.9\end{array}$ & $\begin{array}{l}16 \\
18 \\
18\end{array}$ & $\begin{array}{l}18.2 \\
56.6\end{array}$ & $\begin{array}{r}20.9 \\
54.9\end{array}$ \\
\hline & 100.0 & 100.0 & & & & 18 & 45.0 & 22.6 & 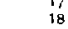 & & & & & $\begin{array}{l}54.9 \\
71.6\end{array}$ \\
\hline & $\begin{array}{r}70.7 \\
100.3\end{array}$ & $\begin{array}{l}74.4 \\
90.4\end{array}$ & $\begin{array}{l}10 \\
11\end{array}$ & 59.1 & $\begin{array}{r}59.8 \\
111.8\end{array}$ & 19 & $\begin{array}{l}27.6 \\
27\end{array}$ & 27.5 & 19 & 13.7 & 14.6 & 232 & 18.2 & 18.7 \\
\hline & 87 & 88.4 & 12 & 31.4 & 33.0 & & 13.2 & $\begin{array}{l}19.3 \\
13.1\end{array}$ & 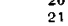 & $\begin{array}{l}39.9 \\
40.5\end{array}$ & $\begin{array}{l}37.2 \\
41.92\end{array}$ & 7 & $\begin{array}{l}21.22 \\
62.0\end{array}$ & $\begin{array}{l}18.2 \\
62.3\end{array}$ \\
\hline & $\begin{array}{r}29.0 \\
25.6\end{array}$ & 29.9 & 13 & & & & 9.3 & 6.2 & 22 & 14.9 & 17.1 & 8 & 20,1 & $\begin{array}{l}24.3 \\
24.2\end{array}$ \\
\hline & 34.4 & 36.3 & 18 & $\begin{array}{r}135.6 \\
60.7\end{array}$ & 60.7 & 6 & $\begin{array}{l}11,0 \\
55,0\end{array}$ & 11.9 & $13^{23}$ & 10.2 & 12.7 & 9 & 17.0 & 18.1 \\
\hline & 31 & 35.0 & 20 & 24.0 & 24.3 & 8 & 24.1 & 26.4 & & $\begin{array}{l}18.4 \\
18.9\end{array}$ & 18.5 & 13 & 29.3 & 3.6 \\
\hline & 1092 & 107.6 & & 33.2 & 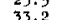 & 10 & $\begin{array}{lll}18.7 \\
0.7\end{array}$ & $\begin{array}{l}20.1 \\
20.6\end{array}$ & 3 & $\begin{array}{l}22.1 \\
12\end{array}$ & 19.1 & $1 t_{4}$ & 17.0 & 17.9 \\
\hline & & & 23 & & & 13 & & & & 75.6 & & & & \\
\hline & $\begin{array}{l}34.5 \\
4.6\end{array}$ & 36.2 & 第 & $\begin{array}{ll}11.3 \\
60.3\end{array}$ & 9.2 & 14 & 16.0 & 18.0 & 9 & 25.2 & 25,0 & 17 & 24.9 & 22.5 \\
\hline & & & & 37.3 & $\begin{array}{l}30 \\
36\end{array}$ & & 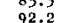 & 91. & 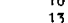 & 34.8 & & & & \\
\hline & 43.6 & 46.2 & 030 & 67.8 & 67.2 & 6 & 95.2 & & $i_{4}$ & 21.7 & & & 8 & $: 0_{3}^{\circ}$ \\
\hline & $\begin{array}{l}30.7 \\
1.7\end{array}$ & $\begin{array}{l}30.0 \\
30.0\end{array}$ & & 17.3 & 14. & 10 & 25.2 & 21. & 17 & 27.4 & 24 & 2 & & \\
\hline & 19 & 18 & 6 & 80 & 80 & 18 & $\begin{array}{l}30.2 \\
25.1\end{array}$ & $\begin{array}{l}28.4 \\
25.44\end{array}$ & $\begin{array}{l}18 \\
18 \\
20\end{array}$ & $\begin{array}{r}25.3 \\
36.5\end{array}$ & $\begin{array}{r}23.7 \\
34.6\end{array}$ & 3 & $\begin{array}{ll}31.2 \\
37.2\end{array}$ & 3 \\
\hline & & 30 & & & & 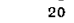 & & & & & & & & 86 \\
\hline & $\begin{array}{r}34,0 \\
3,0\end{array}$ & 32.2 & 年 & 23.0 & 23.3 & $\begin{array}{l}24 \\
24\end{array}$ & 16.4 & 18.4 & 0 & 3.5 & & 7 & 39.1 & 38.7 \\
\hline & & 45.7 & & 49 & 49 & 20 & 349 & (10.3. & 4 & ${ }_{2}^{9}$ & & & & \\
\hline & 51.2 & 49.1 & 040 & 36.2 & 35.1 & 1 & 17.3 & 20. & 6 & 60.4 & 60.4 & & 39.0 & . \\
\hline & $\begin{array}{r}2,0 \\
14,2\end{array}$ & $\begin{array}{l}16.2 \\
0.28\end{array}$ & 1 & $\begin{array}{l}0.0 .0 \\
29.1\end{array}$ & 02.1 & $\frac{2}{3}$ & $\begin{array}{l}17.2 \\
23.4\end{array}$ & $\begin{array}{l}20 \\
21\end{array}$ & $\begin{array}{l}12 \\
16 \\
16\end{array}$ & & $\begin{array}{l}28.6 \\
17.3\end{array}$ & & & 16.5 \\
\hline & $\begin{array}{l}11.0 \\
16.4\end{array}$ & $\begin{array}{r}9.9 \\
15.5\end{array}$ & 3 & $\begin{array}{l}39.8 \\
51.8\end{array}$ & $\begin{array}{l}39.3 \\
51.3\end{array}$ & 4 & $\begin{array}{r}16.7 \\
8.5\end{array}$ & $\begin{array}{r}12.6 \\
8,5\end{array}$ & 154 & 6.6 & $\begin{array}{r}5.3 \\
10.5\end{array}$ & 2 & ${ }^{16.8}$ & 11.6 \\
\hline & 25.0 & 25.3 & 6 & 61.4 & 610 & 6 & 15.6 & 16.6 & & 47.0 & 49.1 & & $\begin{array}{l}52.4 \\
52.5\end{array}$ & $\begin{array}{l}52.3 \\
52,8\end{array}$ \\
\hline & $\begin{array}{l}41,0.0 \\
83\end{array}$ & 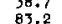 & 8 & $\begin{array}{l}54.4 \\
362\end{array}$ & $\begin{array}{l}53,6 \\
35.6\end{array}$ & 7 & 90.3 & 90.1 & & $30.4^{3}$ & $\begin{array}{l}15.2 \\
305\end{array}$ & & & \\
\hline & $\begin{array}{r}57.5 \\
34.5\end{array}$ & $\begin{array}{r}60.0 \\
33.0\end{array}$ & 9 & $\begin{array}{l}14.6 \\
41.6\end{array}$ & $\begin{array}{l}14.9 \\
3.9\end{array}$ & 9 & $\begin{array}{l}30.7 \\
37.7\end{array}$ & 30.7 & & 71.1 & 74.3 & & & \\
\hline & & & & & & & & & & & & & & \\
\hline
\end{tabular}

The crystal was mounted on the diffractometer with the $a$ axis as rotation axis. 305 reflections were collected and the intensities corrected in the usual way including an absorption correction for the prismatic shape of the crystal.

\section{Refinement}

Structure factors were calculated using the coordinates given by BeEvers and Ross. In their final conclusion about the position of the two sodium atoms in the cell they had considered equipoint $2 d$ on $\left[\frac{211}{3} \frac{1}{4}\right]$ the most probable one. We retained this assumption for the first stage of our refinement. The purpose of this procedure was to obtain a three-dimensional electron-density map of the crystal structure.

Only one scale factor was used in the refinement. Reflections were nitially assigned equal weights but were weighted by $2.5 / F_{0}$ in the final cycles. Scattering curves for half-ionized atoms were employed. The full-matrix least-squares refinement program SFLSQ3 written by C. T. PrewitT was used on the IBM 7094 computer. 
The original atom coordinates with the best fit of scale factor and isotropic temperature factors yielded an $R$ value of $33.7 \%$. With more than nine observations per variable six cycles of refinement varying all parameters led to convergence and a disagreement factor of $5.4 \%$.

Electron-density maps synthesized on the basis of the refined structure factors showed a spherical distribution of the electron density for all aluminum and oxygen atoms within the 'spinel blocks'. The observed electron density agrees with that expected by the original model.

To investigate the location of the sodium atoms, three-dimensional electron-density maps were produced assuming no scattering material between the two adjacent blocks of cubic closest packed oxygen atoms. These maps revealed additional electron density in the special positions $\left[\frac{12}{3} \frac{1}{3}\right]$ and $\left[\frac{21}{3} \frac{1}{4}\right]$. The shape of these 'electron clouds' was not spherical, but approximated a rotational ellipsoid with the (shorter) rotation axis parallel $\overline{\mathbf{6}}$. The ellipsoid at $\left[\frac{21}{3} \frac{1}{4}\right]$ was flatter than that at $\left[\frac{12}{3} \frac{1}{4}\right]$. These are equipoints $2 d$ and $2 c$ for sodium and oxygen, respectively, as suggested by BEEvers and Ross (1937).

Taking full occupancy of these equipoints into account another refinement cycle yielded abnormally high temperature factors for both atoms. Scattering curves for both neutral and half-ionized atoms were tried without any significant change in these factors. Extensively negative areas turned up in both locations on electron-density difference maps using structure factors based on more reasonable temperature factors.

Table 3. Final atomic parameters

\begin{tabular}{|c|c|c|c|c|c|c|c|}
\hline \multirow[t]{2}{*}{ Atom } & \multirow[t]{2}{*}{$\begin{array}{l}\text { Equi- } \\
\text { point }\end{array}$} & \multicolumn{4}{|c|}{ Coordinates } & \multicolumn{2}{|c|}{$\begin{array}{c}\text { Temperature } \\
\text { factor }\end{array}$} \\
\hline & & $\begin{array}{ll}x & \left(\sigma_{x}\right)\end{array}$ & $y \quad\left(\sigma_{y}\right)$ & $z \quad\left(\sigma_{z}\right)$ & $z_{\mathrm{BR}} *$ & $B$ & $\sigma_{\mathrm{B}}$ \\
\hline $\mathrm{Al}(1)$ & $12 k$ & $0.1665(2)$ & $0.3331(4)$ & $0.6060(1)$ & 0.606 & $0.46 \AA^{2}$ & 0.02 \\
\hline $\mathrm{Al}(2)$ & $4 f$ & $1 / 3$ & $2 / 3$ & $0.0248(1)$ & 0.022 & 0.38 & 0.05 \\
\hline $\mathrm{Al}(3)$ & $4 f$ & $1 / 3$ & $2 / 3$ & $0.1753(1)$ & 0.178 & 0.38 & 0.05 \\
\hline $\mathrm{Al}(4)$ & $2 a$ & 0 & 0 & 0 & 0 & 0.42 & 0.07 \\
\hline $\mathrm{Na}$ & $2 d$ & $2 / 3$ & $1 / 3$ & $1 / 4$ & $1 / 4$ & 1.86 & 0.48 \\
\hline$O(1)$ & $12 k$ & $0.1624(4)$ & $0.3249(8)$ & $0.0496(1)$ & 0.05 & 0.69 & 0.06 \\
\hline$O(2)$ & $12 k$ & $0.5016(3)$ & $0.0032(6)$ & $0.1464(1)$ & 0.144 & 0.39 & 0.05 \\
\hline$O(3)$ & $4 f$ & $1 / 3$ & $2 / 3$ & $0.5540(3)$ & 0.55 & 0.36 & 0.08 \\
\hline $\mathrm{O}(4)$ & $4 e$ & 0 & 0 & $0.1421(3)$ & 0.144 & 0.43 & 0.09 \\
\hline$O(5)$ & $2 c$ & $1 / 3$ & $2 / 3$ & $1 / 4$ & $1 / 4$ & 0.96 & 0.24 \\
\hline
\end{tabular}

* The subscript BR refers to the original values of the $z$ coordinates given by Befevers and Ross

Z. Kristallogr. Bd. 127, 1-4 
This feature led to the assumption that the positions of sodium and oxygen within the interlayer are not fully occupied. Taking only fractions of these atoms into account additional cycles of refinement yielded reasonable temperature factors for sodium $\left(1.86 \AA^{2}\right)$ and for oxygen $\left(0.96 \AA^{2}\right)$. According to these temperature factors the occupancy of the sodium position was diminished to $35 \%$ and that of the oxygen position to $82 \%$.

Two final cycles of refinement varying the parameters of all atoms in the cell led to convergence and reduced the $R$ factor to $4.3 \%$. The atomic parameters and their standard deviations based on the final structure-factor computation are given in Table 3.

\section{Discussion of the structure}

The picture of the crystal structure shown in Fig. 1 yields the impression of two areas of different stability. The less stable interlayer of sodium and oxygen atoms in the mirror plane perpendicular to the $c$ axis is of special interest in the present work. BrAGG, GotTFrIED and WEST (1931) assigned the structure to $P 6_{3} / m m c$. This assignment has been improved and retained in the present work. The unit cell consists of two blocks, each with four layers of oxygen atoms. They are closest packed and contain aluminum atoms in tetrahedral and octahedral coordination on positions identical with those of the aluminum and magnesium atoms in the structure of spinel. The arrangement of the atoms inside the 'spinel blocks' has been confirmed by the small disagreement factor $R$ computed for the refined structure. The interatomic distances are listed in Table 4.

The 'spinel blocks' form plates parallel to (0001) of unlimited extension. Two adjacent blocks related to each other by a mirror plane are joined together by a layer of oxygen and sodium atoms which is not closest packed and therefore less stable than the packing of the blocks.

The problem discussed in the paper of BeEvers and Ross (1937) as to whether the sodium atom is occupying the position of equipoint $2 d$

Table 4. Interatomic distances

\begin{tabular}{ll|ll}
\hline $\mathrm{Al}(1)-\mathrm{O}(1)$ & $2.039 \pm 0.001 \AA$ & $\mathrm{Al}(2)-\mathrm{O}(1)$ & $1.748 \pm 0.001 \AA$ \\
$\mathrm{Al}(1)-\mathrm{O}(2)$ & $1.861 \pm 0.001$ & $\mathrm{Al}(2)-\mathrm{O}(3)$ & $1.777 \pm 0.002$ \\
$\mathrm{Al}(1)-\mathrm{O}(3)$ & $1.997 \pm 0.002$ & $\mathrm{Al}(3)-\mathrm{O}(2)$ & $1.727 \pm 0.002$ \\
$\mathrm{Al}(1)-\mathrm{O}(4)$ & $1.807 \pm 0.002$ & $\mathrm{Al}(3)-\mathrm{O}(5)$ & $1.683 \pm 0.002$ \\
$\mathrm{Al}(4)-\mathrm{O}(1)$ & $1.930 \pm 0.001$ & $\mathrm{Na}-\mathrm{O}(2)$ & $2.839 \pm 0.001$
\end{tabular}


$\left[\frac{21}{3} \frac{1}{4}\right]$ or $2 b\left[00 \frac{1}{4}\right]$ is solved quite clearly by the three-dimensional data

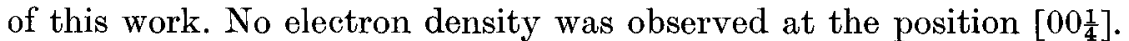

More detailed information was obtained about the situation in the sodium-oxygen layer, especially about the sodium position. The refinement cycles varying the occupancy and the temperature factors led to the conclusion that the positions of equipoint $2 d$ and $2 c$ are only partially occupied by sodium and oxygen respectively. However

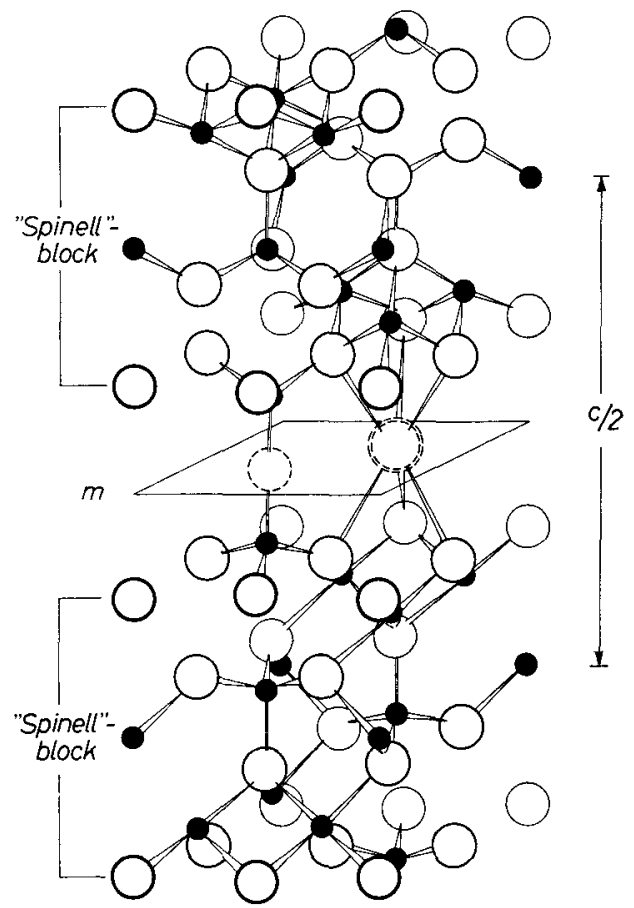

Fig. 1. Refined structure of sodium beta alumina showing cation-anion bonds. Black circles represent aluminum atoms, clear circles oxygen atoms. Dotted circles indicate the positions of oxygen $\left[\frac{1}{3} \frac{2}{3} \frac{1}{4}\right]$ and sodium-larger circle- $-\left[\frac{1}{3} \frac{2}{4}\right]$ which are not fully occupied

the proportion of $35 \%$ partial occupaney for sodium to $82 \%$ for oxygen is not quite satisfactory because of the excess of oxygen. The final electron-density difference map yields an answer to this problem: There is some remaining electron density indicated in the shape of a flat corona around the sodium position $\left[\frac{2}{3} \frac{1}{3}\right]$ with the inside diameter of $1.6 \AA$ and some further electron density in the direction of the oxygen atoms of equipoint $12 k$. These oxygen atoms are nearest neighbors to 
the sodium atom, which thus realizes six coordination. The distance of $2.84 \AA$ from the sodium position $\left[\frac{2}{3} \frac{1}{3} \frac{1}{4}\right]$ to the six oxygen atoms in the adjacent blocks is still considered too large to provide sufficient stability. This was previously mentioned by BeEvers and Ross (1937), who found a distance of $2.89 \AA$.

According to SAALFELD and Kato (private communication), who succeeded in extracting all sodium without distortion of the betaalumina structure, the $\mathrm{H}_{3} \mathrm{O}^{+}$-ion may assume the stabilizing function of the sodium in the structure. For our problem it means, that hydrogen atoms forming $\mathrm{O} \cdots \mathrm{H}$ bonds with the oxygen atoms on equipoint $12 k$ may be indicated by the remaining electron density on $\left[\frac{21}{33} \frac{1}{4}\right]$, as described above.

The sodium-oxygen interlayer of the beta-alumina structure is to be considered disordered. According to the possible $\mathrm{Na}^{+}-\mathrm{H}_{3} \mathrm{O}^{+}$-ion exchange the specimen studied in this work represents just one stage in the transition from one endmember, $\mathrm{Na}_{2} \mathrm{Al}_{22} \mathrm{O}_{34}$, to the other, $\mathrm{H}_{6} \mathrm{Al}_{22} \mathrm{O}_{36}$, in which all sodium is replaced by $\mathrm{H}_{3} \mathrm{O}^{+}$. The mechanism of ion exchange may include the formation of holes as indicated by the deficiency of matter on $\left[\frac{21}{3} \frac{1}{3} 1\right]$ and $\left[\frac{12}{3} \frac{1}{4}\right]$ in this crystal.

\section{Acknowledgements}

The author is indebted to Professor M. J. Buerger for having supported this work generously and to Professor H. SAalfeld, Hamburg, Germany, who suggested this study. The author is especially grateful to L. Waldrop, F. Trojer, R. Beger and Professor B. Wuensch for their various profitable impulses and discussions. The computations were carried out at the Massachusetts Institute of Technology Computation Center by the support of the National Science Foundation. The author was the holder of a fellowship from the Deutsche Forschungsgemeinschaft, Bad Godesberg, West Germany.

\section{References}

C. A. Beevers and M. A. S. Ross (1937), The crystal structure of 'beta alumina' $\mathrm{Na}_{2} \mathrm{O} \cdot 11 \mathrm{Al}_{2} \mathrm{O}_{3}$. Z. Kristallogr. 97, 59-66.

W. L. BragG, C. GotTFrited and J. West (1931), The structure of $\beta$ alumina. Z. Kristallogr. 77, 255-274.

S. B. Hendricks and L. Pauling (1927), Die Struktureinheit und Raumgruppensymmetrie von $\beta$-Aluminiumoxyd. Z. Kristallogr. 64, 303-308.

$\mathrm{H}$. SAALFELD (1956), Umwandlung von $\alpha-\mathrm{Al}_{2} \mathrm{O}_{3}$ in $\beta-\mathrm{Al}_{2} \mathrm{O}_{3}$. Z. anorg. allg. Chem. 286, 174-179.

C. W. Stildweld (1926), Color of the ruby. J. Physic. Chem. 30, 1441-1466. 